\title{
COMMUNITY SERVICE TEACHERS' COMPETENCY IMPROVEMENT IN SAMOSIR DISTRICT TOWARDS TOURISM CITY
}

\author{
Elvi Mailani ${ }^{*}$, Yusnizar Heniwaty ${ }^{2}$, Vidya Dwi Amalia Zati ${ }^{2}$ \\ ${ }^{I}$ Elementary Teacher Education, Faculty of Education, Medan State University, Medan, Indonesia \\ ${ }^{2}$ Dance Education, Faculty of Language, Art, and Literature, Medan State University, Medan, Indonesia \\ *Corresponding Author: elvimailani@gmail.ac.id
}

\begin{abstract}
Partners who are the target of community service program are teachers in Samosir District area. Samosir was chosen because the position of the region was on the shores of Lake Toba, and according to the vision and mission of the Samosir District government, Samosir will become a tourism city. Teacher competencies and abilities must also be improved in order to be able to support the mission and vision. Based on observations and interviews there are 2 main problems faced by partners, includes: (1) pedagogical competencies, (2) professional competencies. Based on these problems, several solutions were offered, including: workshop and mentoring activities. Specific targets and outputs that will be generated in community service program includes: (1) learning program plan (2) book of questions bank, (3) book and CD of songs and dance collections in Batak area, (4) Guidance book on 2013 curriculum, (5) model teacher of English language, Nntural sciences and mathematics lessons. The implementation of community service program to improve teacher competency in Samosir District will be carried out in a gradual, sustainable and comprehensive manner. This process is carried out through workshop and mentoring methods to provide provision and improvement of competencies for teachers which can later be implemented in the learning process in the classroom as an effort to improve students' abilities in realizing the vision and mission of Samosir Regency towards a tourism city.
\end{abstract}

Keywords: Teachers' Competency Accompaniment.

\section{INTRODUCTION}

Samosir Regency is one of the districts in the North Sumatra Province. The regency, which is $170 \mathrm{~km}$ from the city of Medan, is in the area of Lake Toba which is a symbol of tourism in North Sumatra Province. The existence of Samosir regency in the area which is the number one tourist visit in North Sumatra, certainly has a positive influence on the development and progress of this district. The Samosir district government certainly hopes that the existence of the community in the area of Lake Toba tourism area, especially all residents of Samosir Regency can take part in efforts to advance tourism in Samosir Regency.

Efforts to advance, bring and make tourists feel at home when they come to Samosir Regency are also expected to come from school children from elementary, middle and high school levels. In this case the local government cooperates with the Samosir district education office, seeks to involve all students in Samosir Regency to become tourism ambassadors, who can promote the region and culture which are tourist attractions in Samosir Regency. To make students especially elementary school students become tourism ambassadors who are expected to be able to promote tourism in the Samosir Regency area, of course communication skills are needed in various languages, especially English and artistic abilities related to the culture of Samosir Regency. English language skills and artistic abilities are expected to be mastered by students, of course it does not come by itself, but the mechanistic abilities that must be learned and trained in elementary schools in particular.

The ability or competence of teachers who can equip students in English language skills, cultural arts and mathematics, of course, must always be honed and improved in order to realize the expectations of the Samosir Regency government. Efforts to improve teacher competency in the various competencies mentioned above continue to be carried out by the government, for example by upgrading, debriefing, seminars, discussions, until research which essentially aims to improve the quality of teachers, especially teachers who teach English subjects, cultural arts, mathematics and science. In a narrower scope, teachers also face the classic problem, namely that there are some teachers whose teaching competencies have not met the proper demands. Mastering the material taught is not enough. $\mathrm{He}$ must be able to convey the subject matter well. The meaning of "well" here is inherent in it, speaking clearly; selection of the right method; use of appropriate learning approaches and models; the use of effective learning media; 
the teacher's assessment of the actual results must be authentic, up to his physical appearance (movements in class, facial expressions, expressions, etc.). The role of the teacher is very decisive in efforts to improve the quality of formal and formal education. For that teachers as agents of learning are required to be able to carry out the learning process as well as possible, within the framework of educational development. The teacher has a very strategic function and role in the development of the education sector, and therefore needs to be developed as a dignified profession.

11 Hutabolon Public Elementary School, Pangururan Subdistrict, Samosir Regency is a school that will be the location for the LPM of Medan State University. The location of the school is very strategic because it is located on Samosir Island which is very convenient for the place of teaching and learning. 11 Hutabolon Public Elementary School is on Simanindo-Pangururan Road KM 10 Hutabolon Pangururan District, Samosir Regency. This school is located in the hinterland where the majority of the population are farmers and fish sprouts and Christianity. The number of educators in this school is 8 people with 150 students. The curriculum used in SD Negeri 11 Lutabolon, Pangururan Subdistrict, is the 2013 curriculum, but in reality the teachers who teach at 11 Hutabolon Public Elementary Schools still have problems in implementing the teaching and learning process using the 2013 curriculum. The profile of 11 Hutabolon Public Elementary School in Pangururan District, Samosir Regency can be seen in the table below:

Table 1. Profile of 11 Hutabolon Public Elementary Schools.

\begin{tabular}{|l|l|l|}
\hline No & \multicolumn{1}{|c|}{ Identity } & $\begin{array}{l}\text { 11 Hutabolon Public Elementary School, Pangururan } \\
\text { Subdistrict, Samosir Regency }\end{array}$ \\
\hline 1 & Name & 10208976 \\
\hline 2 & NPSN & Pangururan Subdistrict, Samosir Regency \\
\hline 3 & Address & Education \\
\hline 4 & Business fields & Rismauli Sinaga \\
\hline 5. & Headmaster & 8 people \\
\hline 6 & Total number of teachers & 150 Children \\
\hline 7 & Total number of students & Local government \\
\hline 8 & Funding & \\
\hline
\end{tabular}

Based on the situation analysis and interviews conducted by the PKM team from Medan State University to 11 Hutabolon Public Elementary School, Samosir Regency, various problems were currently faced by teachers and stakeholders in this elementary school. Problems that appear to be more dominated by abilities are closely related to teacher competency as the main pillar of the learning process in the classroom. From the various problems found by the PKM team, the priority issues faced by Hutabolon District 11 Samosir District 11 can be detailed as follows: (a) the ability of teachers to design active lesson plans is still low, (b) teachers still have problems in making questions related to cognitive, affective and psychomotor abilities, (c) the ability of teachers in the field of cultural arts is low, (d) teachers' understanding of the 2013 curriculum is still very low, (e) teacher skills in teaching English are still lacking, and (f) understanding of teacher concepts Mathematics and Natural Sciences subjects are still very low.

Based on these problems, the solutions offered by the Unimed LPM PKM team are: (a) workshops and mentoring in designing lesson plans, (b) workshops and mentoring in making questions related to cognitive, affective and psychomotor abilities, (c) mentoring in the arts and culture , (d) workshops on the 2013 curriculum, (e) workshops and mentoring in training teacher skills in English lessons, and (f) workshops and mentoring for MIPA learning. The outcomes of this activity are: (a) RPP active learning, (b) Question Bank book, (c) Batak Toba dance CD and music, (d) 2013 curriculum guidelines, (e) English pocket book and (f) model teacher math and natural science lessons.

\section{IMPLEMENTATION METHOD}

The stages of the implementation of the community partnership program (PKM) assistance in increasing the competence of teachers at 11 Hutabolon Public Elementary Schools in Pangururan District, Samosir Regency, North Sumatra Province were carried out based on the problems seen at 11 Hutabolon Elementary Schools in Pangururan Subdistrict which were partners in this partnership program. achieving the objectives of the partnership program activities, the methods for implementing the activities are carried out in several stages, including: (1) preparation, (2) implementation, (3) monitoring and evaluation, and (4) follow-up. The method of implementing the activities in the picture above can be explained as follows:

\subsection{Preparation}

a. Initial observations aimed at obtaining school profiles.

b. Agreement on issues faced by partners aims to determine partner priority issues that need to be given assistance.

c. Agreement on solutions to problems faced that aim to discuss methods or forms of activities in finding solutions to problems. 


\subsection{Implementation}

a. Workshops and mentoring in the preparation of the RPP which includes active learning, where it is hoped that in the learning activities students' activities will be prioritized.

b. Mentoring for teachers in designing assessments which include cognitive, affective and psychomotor aspects

c. Mentoring in improving the competence of arts and culture of teachers, especially Toba Batak songs and dances which can later be taught to students as a provision in their daily lives in society.

d. Workshop and assistance in understanding the teachers about the 2013 curriculum.

e. Competency assistance for English teachers, math teachers and science teachers.

\subsection{Monitoring and Evaluation}

a. Process evaluation that aims to monitor and measure the effectiveness of the mentoring implementation process carried out by looking at and observing the teacher's understanding.

b. Evaluation of results aims to see the impact and effectiveness of workshops and mentoring carried out on teachers to students of SDN 11 Hutabolon, District of Pangururan, Samosir Regency.

Program sustainability efforts in an effort to improve the results of activities that have been obtained. This activity was carried out on a broader scale with the study and implementation of activities in other themes

Community partnership program (PKM) mentoring the improvement of competence of teachers at 11 Hutabolon Elementary Schools in Pangururan Subdistrict, Samosir Regency, North Sumatra Province aims to improve the competence of teachers and stakeholders who teach at the school. Teacher and teaching team competencies need to be improved because teachers and teaching teams are the leading figures in efforts to provide students with supplies and insights for their lives in the future. Workshops and mentoring are conducted with the aim of providing knowledge and skills for teachers in terms of improving their competence as an educator and teacher.

Program evaluation will be carried out starting from the planning, implementation, and results of each activity. The evaluation is not only on the results, but the process of implementing this activity is done to find out the constraints and obstacles that are felt and experienced by both the teacher as the participant and the object of the activity, as well as the constraints and constraints felt by the implementation team of service activities.

After the problems found can be addressed effectively, then the next program or activity is carried out. This is what is said with the sustainability of the program. The program will continue if one main activity can be completed properly. However, if there are obstacles in implementing the main program, the next program cannot be continued. The sustainability of the activities will be carried out in the form of activities: (1) making the 11 Hutabolon Elementary Schools in Pangururan sub-district become Unimed's LPM target schools, and (2) carrying out ongoing mentoring and guidance activities on a broader scale.

\section{RESULTS AND DISCUSSION}

\subsection{Preparation of Service Activities}

a. Preparation arrangements for service activities starting from team assignment arrangements, coordination with Unimed Community Service Institution elements and strengthening agreements with service partner schools to bring together views on the plans and procedures for conducting research.

b. Strengthening and signing of the MoU with the school where the activities were held

c. Schedule a workshop agenda and mentoring to improve the competency of teachers in Samosir Regency.

\subsection{Implementation}

After the initial analysis of the problems with teachers at 11 Hutabolon Public Elementary School in Pangururan, Samosir Regency, several stages of service delivery were carried out in the form of workshops and mentoring activities at 11 Hutabolon Public Elementary School, Pangururan, Samosir Regency.

\subsubsection{Training and Mentoring Making Learning Implementation Plans That Contain Active Learning Processes}

The learning implementation plan (RPP) is a plan that must be owned by a teacher when he will carry out the learning process in the classroom. RPP is the heart of a learning process. During this time the lesson plan made by the teacher, especially at 11 Hutabolon Public Elementary School in Pangururan, Samosir Regency was based on observations and interviews with teachers, still limited to copy paste from the internet or limited to copying from other teachers either from the school itself, or from other schools. RPP used by the teacher so far in the learning process has not seen the learning steps that are arranged reflecting the active learning process.

The workshop and mentoring activities were carried out by a team of 11 Hutabolon Elementary School teachers in Pangururan District, Samosir Regency, in an effort to provide skills in the design and preparation of learning implementation plans (RPP) which included various active learning strategies. After conducting workshops and mentoring for teachers at 11 Hutabolon Elementary School in Pangururan District, Samosir Regency, it was seen that 
the teacher's ability to design learning implementation plans (RPP) which included the active learning process became more increasing. Teachers of 11 Hutabolon Elementary Schools in Pangururan District, Samosir Regency have been able to make lesson plans that contain various models and active learning approaches that aim to explore students' competencies and abilities when the learning process takes place.

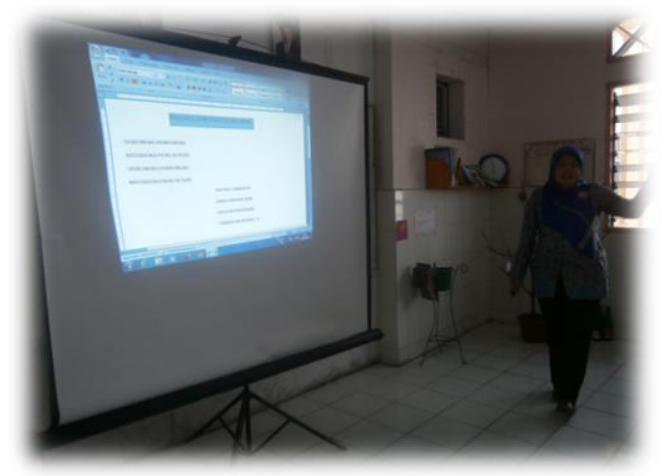

Figure 1. Assistance in Preparation of Learning Plans.

\subsubsection{Workshop and Mentoring on Question Making}

The workshop activities and problem-making assistance aimed at equipping teachers in designing questions that would later be used to measure the achievement of students' understanding of the material that had been studied in cognitive, affective and psychomotor aspects. From the results of workshops and teacher assistance in making questions, it is expected that the teacher's ability to design questions will be better. The process of designing questions is more directed and the teacher is also expected to be able to make rubric and the grid needed to design a problem. Other results are expected from this activity the teacher has a question bank book that can help teachers improve student competencies in the future.

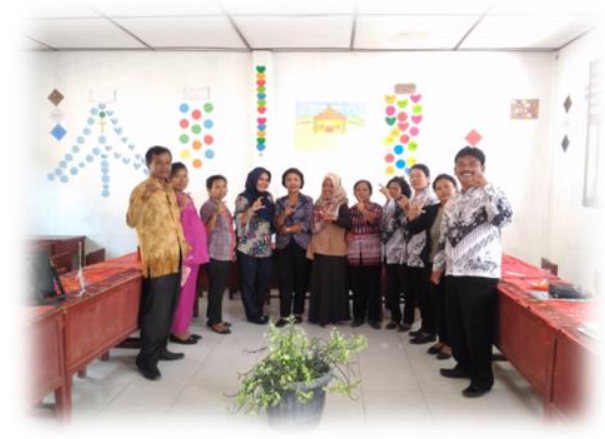

Figure 2. Assistance in Preparation of Learning Plans.

\subsubsection{Training and Mentoring for Enhancing Art and Culture Skills}

One aspect that can support the vision and mission of the Samosir district government in realizing Samosir towards the city of tourism, is on the aspects of art and culture which become the main attraction of tourists who come from Indonesia and tourists from overseas. Ability here and culture are mechanistic abilities that will be better if they are constantly honed and trained. The ability of elementary school students to offer art and culture is not better if it is not honed by their teacher. The role of teachers is very vital in an effort to improve students' art competencies.

After the workshop and mentoring activities are complete, it is expected that the ability of teachers in terms of cultural arts will be more improved and have creative ideas that can be channeled in the arts and culture in order to add wealth to the treasures and regional culture especially in Samosir district. The teacher's ability to improve in terms of art and culture is expected to be able to be balanced to students / I especially at the elementary school level in order to be able to help the vision and mission of the Samosir Regency government in realizing Samosir as a tourist city.

\subsubsection{Curriculum Workshop}

Observations made before the service was conducted, it was seen that the ability of teachers who became partners in the implementation of the 2013 curriculum was still very low. This is what underlies the workshops and mentoring activities in providing understanding to teachers about the 2013 curriculum. It is hoped that after the workshop and mentoring activities will be completed, the teachers will open their insights and understanding of the 2013 curriculum implementation process. The 2103 curriculum and mentoring activities are important for teachers, so that they are able to understand the various concepts contained in the 2013 curriculum and how to apply them. in the teaching and learning process in the classroom. As a result of this activity it is hoped that a guide to the 2013 curriculum and its implementation in the learning process in the classroom will be created that can be used by the teacher as a guideline 
in implementing the 2013 curriculum at 11 Hutabolon Public Elementary School, Pangururan District, Samosir Regency.

\subsubsection{Workshop and Mentoring for Increasing English Competence}

One of the supporting factors that can bring tourism and make tourists who come to feel at home in Samosir district is the ability of citizens to communicate and publicize various tourist visit areas in Samosir Regency. Publication and dissemination of the diversity of tourist objects found in Samosir Regency, of course, requires good and two-way communication delivered by the Samosir community to the tourists who visit Samosir Regency. Good communication skills will certainly facilitate the delivery of messages, especially to tourists who come from abroad. The English ability of all residents in Samosir Kabuaten certainly needs to be honed, not least for students / I at the elementary school level. This training and mentoring aims to provide effective solutions and ways for teachers, especially in teaching English to students at the elementary school level.

\subsubsection{Workshop and Mentoring Improvement of Mathematics and Natural Sciences competencies}

This workshop and mentoring aimed to equip teachers at 11 Hutabolon Elementary School in Pangururan, Samosir District, about skills and abilities in the MIPA field. Skills and abilities in the field of Mathematics and Natural Sciences are certainly useful for students in their lives in the future. Mathematical ability also plays a very big role in making Samosir District a tourism city. If students' mathematical abilities are good, of course students can also help their parents in carrying out trade activities carried out in tourist areas in an effort to support the family economy in particular, and the economy of Samosir Regency in general. For that students' mathematical abilities need to be honed through their respective teachers. For this reason workshops and mentoring for teachers in improving Mathematics and Natural Sciences competencies need to be implemented.

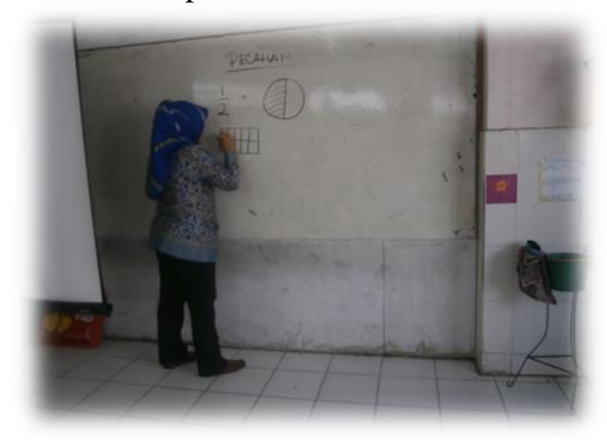

Figure 3. Assistance in Preparation of Learning Plans.

\section{CONCLUSION AND SUGGESTION}

a. Workshop activities and assistance in improving the competence of teachers in Samosir District have had a positive impact on the participation of students and teachers in realizing the vision and mission of the Samosir Regency government to make Samosir a tourist city.

b. The results of the workshops and mentoring that have been carried out have produced results: (1) RPP active learning, (2) question bank books, (3) senitari CDs and Toba Batak songs, (4) 2013 curriculum implementation guidelines (5) English pocket books and (6) mathematics and science model teachers.

c. The principal as the responsible person and manager of the school is continually expected to always remind the teachers in his work area to always develop the competencies and abilities they have to support the vision and mission of the Samosir Regency government to make Samosir a tourist city

d. Teachers must always create positive characteristics in order to realize school programs and programs from the government of Samosir District which is their service area.

\section{REFERENCES}

Kemdikbud. 2013. Panduan Pelaksanaan Penelitian dan Pengabdian Kepada Masyarakat di Perguruan Tinggi (Edisi IX). Jakarta.

Peraturan Pemerintah RI Nomor 74 Tahun 2008. Tentang Guru (Lembaran Negera RI Tahun 2008 Nomor 194). Tim penyusun. 2013. Panduan Pelaksanaan Penelitian dan Pengabdian Kepada Masyarakat Di Perguruan Tinggi Edisi IX. Direktorat Penelitian Dan Pengabdian Kepada Masyarakat Direktorat Jenderal Pendidikan Tinggi Kementerian Pendidikan Dan Kebudayaan. 